\title{
A Patient with Intralobar Pulmonary Sequestration: A Rare Congenital Anomaly
}

\author{
Walter Beneduzzi Fiorotto 1,2 , Leandro Zacarias ${ }^{1,3}$, Marcio Ricardo dos Santos ${ }^{1,2}$, \\ Flavio Borges de Oliveira, ${ }^{1,3}$, Jamil Elias Dib Filho², Gilson Cassen Ramos ${ }^{2}$
}

\begin{abstract}
A 51-year-old male patient had a history of recurrent pneumonia since the second decade of life. Interestingly, chest $\mathrm{X}$-rays indicated the same radiological pattern with left lower lobe involvement. A multislice spiral CT scan of the chest was performed and depicted an anomalous arterial vessel emerging from the descending thoracic aorta towards the left lower pulmonary lobe, characterising pulmonary sequestration. The findings were confirmed by thoracic aortography, and the patient was referred for surgical treatment.
\end{abstract}

DESCRIPTORS: Bronchopulmonary sequestration. Congenital abnormalities. Angiography. Diagnostic imaging.

$\mathbf{P}$ ulmonary sequestration is an anomaly characterised by a non-functioning pulmonary mass without communication with the normal bronchial tree, whose blood supply derives from an anomalous systemic artery. ${ }^{1,2}$ This is a rare anomaly with an incidence of $0.15 \%$ to $6.45 \%$ of congenital pulmonary malformations. ${ }^{3}$ Two forms have been described: extralobar sequestration, which has its own pleura, and intralobar sequestration, which is covered by the visceral pleura of a normal pulmonary lobe. ${ }^{4} \mathrm{~A}$ case of this rare congenital anomaly is reported, highlighting the main findings of the imaging analyses.

\section{CASE REPORT}

A 51-year-old male from the state of Goiás, Brazil, who lives in a rural area, presented with recurrent episodes of pulmonary infection, which were usually difficult to treat, for approximately 28 years. Some episodes

\footnotetext{
Santa Casa de Misericórdia de Goiânia - Goiânia, GO, Brazil.

${ }^{2}$ Hospital Samaritano de Goiânia - Goiânia, GO, Brazil.

${ }^{3}$ Hospital Santa Helena - Goiânia, GO, Brazil.

Correspondence to: Walter Beneduzzi Fiorotto, Praça Walter Santos,

1 - Setor Coimbra - Goiânia, GO, Brazil - CEP 74733-250

E-mail: wbfrep@uol.com.br

Received on: 1/8/2012 • Accepted on: 3/14/2012
}

RESUMO

\section{Paciente com Sequestro Pulmonar Intralobar: Uma Rara Anomalia Congênita}

Paciente do sexo masculino, com 51 anos de idade, com história de pneumonias de repetição desde a segunda década de vida. As radiografias de tórax curiosamente demonstravam o mesmo padrão radiológico com envolvimento do lobo inferior esquerdo. Foi realizada tomografia helicoidal de tórax, que revelou vaso arterial anômalo emergindo da aorta torácica descendente em direção ao lobo pulmonar inferior esquerdo, caracterizando sequestro pulmonar. Os achados foram confirmados por aortografia torácica, sendo o paciente encaminhado para tratamento cirúrgico.

DESCRITORES: Sequestro broncopulmonar. Anormalidades congênitas. Angiografia. Diagnóstico por imagem.

were associated with haemoptysis, which is occasionally abundant. The subject smoked from the age of 17 to 22 years. His past medical history was positive for childhood asthma, Chagas disease (arrhythmogenic type), and pulmonary tuberculosis treated at the age of 24 .

Chest X-rays always indicated a pattern of homogenous hypotransparency in the posterior left lower hemithorax. A chest spiral angiotomography was performed, which indicated (Figure 1):

1) an anomalous blood vessel emerging from the descending aorta towards the left lower lobe without evidence of irrigation from the ipsilateral pulmonary artery for this segment;

2) prominence of arterial and venous vascularisation in the left lower pulmonary fields due to hypertension, without characterisation of arteriovenous communications;

3) mild left pulmonary artery hypoplasia; and

4) mild left lung hypoplasia.

Intralobar pulmonary sequestration was diagnosed, based on these findings. Aortography and heart catheterisation were performed to complement the diagnosis and for surgical planning (Figures 2 and 3). Heart catheterisation indicated coronary arteries without significant obstructions and left ventriculography with 

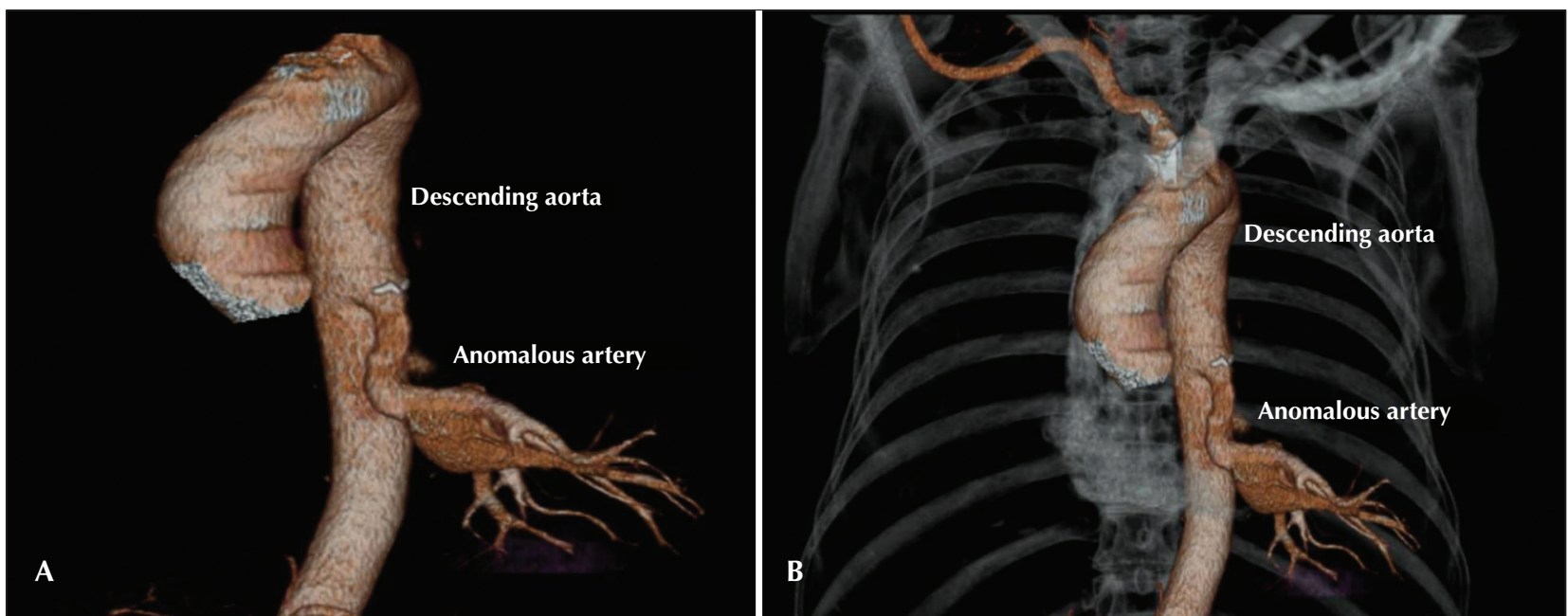

Figure 1 - Chest computed angiotomography. In A and B, the presence of an anomalous artery emerging from the descending aorta into the direction of the left lower lung lobe.

no changes. Aortography demonstrated the presence of a large arterial branch originating from the descending aorta into the lower left lung.

Currently, the patient is asymptomatic and awaiting surgery.

\section{DISCUSSION}

The term 'sequestration' refers to a lung segment with an anomalous arterial vessel. In $80 \%$ of cases, the blood supply of this segment derives from the descending aorta, although the abdominal aorta, the subclavian artery, and the renal artery can also be sources of this arterial vessel. ${ }^{3}$ In the present case, the anomalous arterial supply originated from the thoracic descending aorta.

The classification of extralobar or intralobar pulmonary sequestration depends on the presence or absence of its own pleura. Extralobar pulmonary sequestration, which represents $25 \%$ of the cases, has its own pleura. This type is more prevalent in males (4:1), and it is located in the left hemithorax in $80 \%$ of the cases. Conversely, intralobar pulmonary sequestration is surrounded by normal lung tissue and is equally distributed between genders. It usually affects the left lower lobe.

The symptoms of intralobar pulmonary sequestration usually manifest around the second decade of life as recurrent respiratory infections., ${ }^{2,5}$ This late diagnosis, associated with histopathological findings, indicates that some forms of intralobar pulmonary sequestration may originate from a chronic inflammatory process of an infectious aetiology. ${ }^{1}$ Conversely, extralobar pulmonary sequestration is usually diagnosed during childhood, and it is associated with other congenital anomalies in over $60 \%$ of the cases. ${ }^{6,7}$ For this reason, extralobar pulmonary sequestration is considered to be a congenital disease.

The diagnosis of pulmonary sequestration can be suggested by imaging exams, such as ultrasound with colour Doppler, chest spiral angiotomography, magnetic resonance imaging, and aortography. However, a definitive diagnosis is achieved through an anatomopathological study. ${ }^{8}$

Chest X-ray usually detects opacity in the posterior basal segment of the left lower lobe contiguous with the hemidiaphragm; however, it does not rule out other lesions of a similar aspect, and it does not distinguish between extralobar and intralobar types. ${ }^{8}$

Ultrasound is more useful during the prenatal period and in newborns when it usually identifies an echogenic and homogenous intrathoracic mass with clear edges. ${ }^{3,9}$ Colour Doppler highlights the anomalous artery. Identifying an arterial branch from the thoracic or abdominal aorta using colour Doppler is pathognomonic of sequestration. ${ }^{3,10}$

Arteriography is considered to be the gold standard for diagnosing pulmonary sequestration. It permits the identification of the anomalous artery as well as its origin, number, course, size, and venous drainage, which are invaluable information for preoperative planning. ${ }^{11,12}$ However, spiral angiotomography and magnetic resonance angiography (angioMRI), due to their accuracy and lower invasiveness, are good diagnostic options.

Tomographic findings include the presence of a homogenous mass or cystic formations. Spiral tomography can indicate the origin and course of anomalous systemic vessels. ${ }^{8}$

Angio MRI allows for excellent visualisation of anomalous vessels, and arteriography can be omitted. 

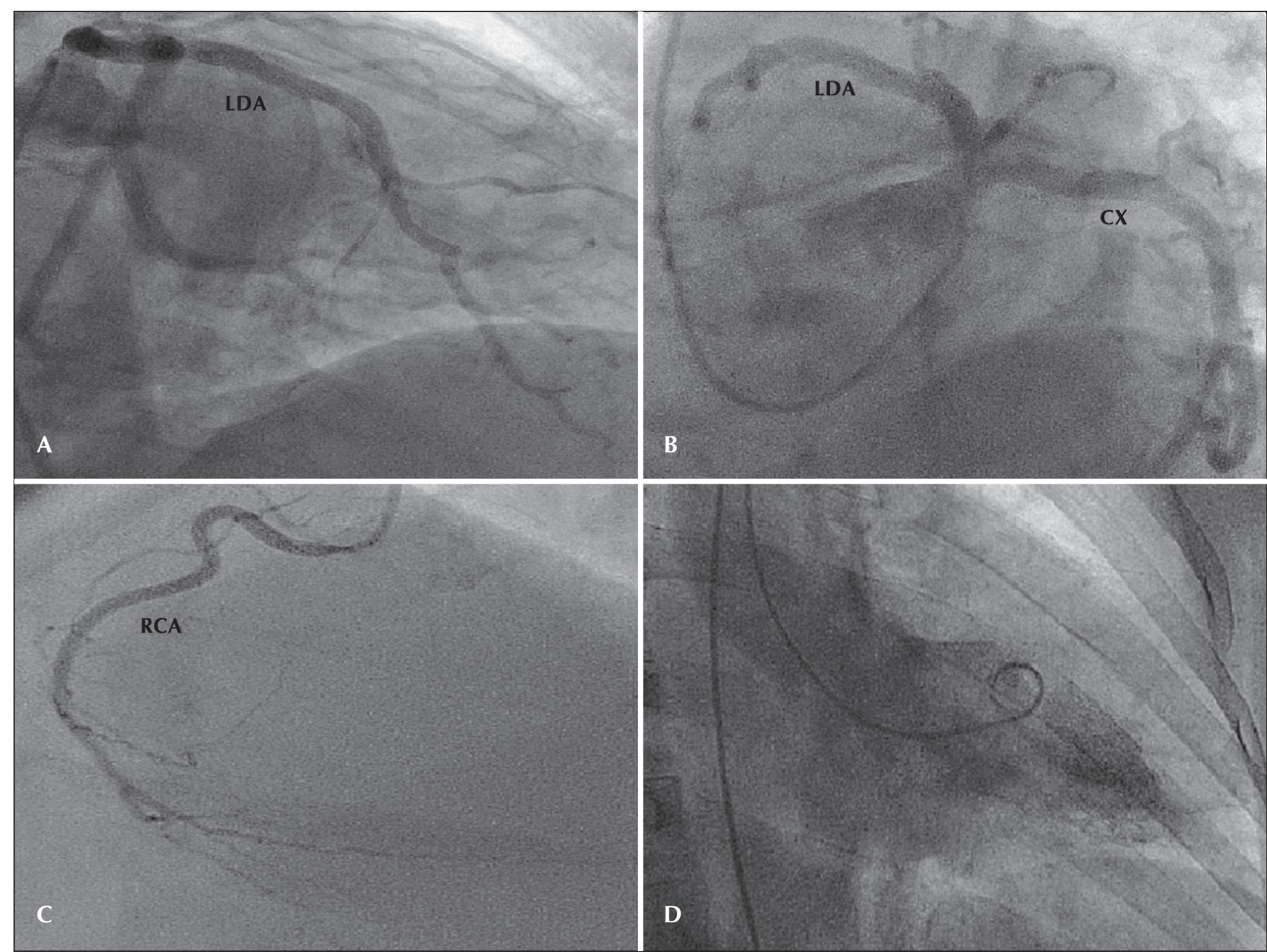

Figure 2 - Coronary angiography. In A and B, anterior descending and circumflex arteries without significant obstructive lesions. In C, right coronary artery without significant obstructive lesions. In $\mathrm{D}$, left ventriculography indicating preserved ventricular function. RCA = right coronary artery; $C X=$ circumflex artery; $L A D=$ left anterior descending artery.

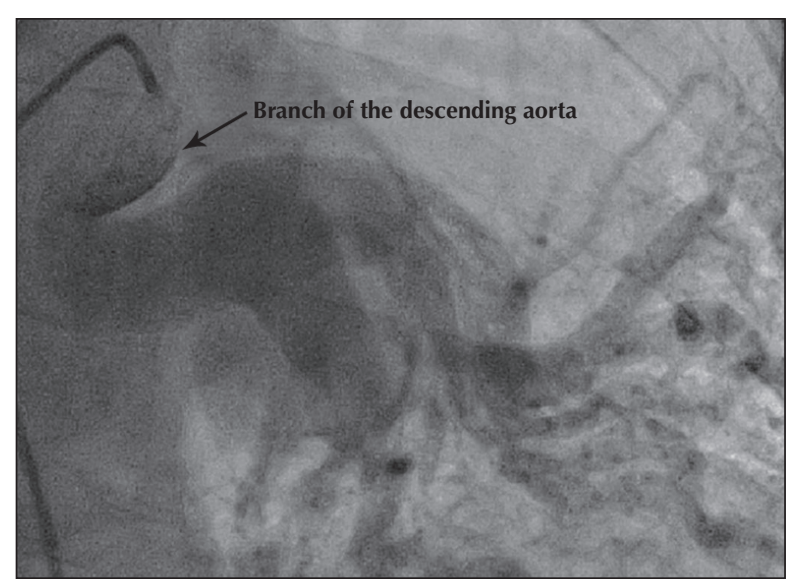

Figure 3 - Selective characterisation and opacification of the anomalous vessel originating from the descending thoracic aorta.

Moreover, angio MRI allows for better characterisation of lung lesions, differentiating cystic, solid, fluid, and hemorrhagic types. ${ }^{8}$
Resection of the involved lung parenchyma is the treatment for pulmonary sequestration. This type of surgery is easier in extralobar pulmonary sequestration because the anomalous mass has its own pleura. Conversely, in the intralobar type, which has the same pleura as the remaining lung and has infectious changes, the surgical procedure can be more difficult. However, after the surgery, postoperative evolution is usually very favourable. ${ }^{13}$

Some authors have proposed a conservative treatment for cases without comorbidities; however, the presence of diseases such as haemoptysis, benign tumours, and pneumonias caused by more aggressive etiologic agents, among others, requires surgical treatment.

It is concluded that, despite the fact that pulmonary sequestration is a rare entity, this possibility should be investigated in patients with recurring pneumonias. Moreover, imaging exams demonstrated great diagnostic value and, for this reason, should be used before any surgical procedure. 


\section{CONFLICTS OF INTEREST}

The authors declare no conflicts of interest.

\section{REFERENCES}

1. Gezer S, Taştepe I, Sirmali M, Findik G, Türüt $H$, Kaya $S$, et al. Pulmonary sequestration: a single-institutional series composed of 27 cases. J Thorac Cardiovasc Surg. 2007;133(4):955-9.

2. Louie HW, Martin SM, Mulder DG. Pulmonary sequestration: 17-year experience at UCLA. Am Surg. 1993;59(12):801-5.

3. Halkic N, Cuénoud PF, Corthésy ME, Ksontini R, Boumghar M. Pulmonary sequestration: a review of 26 cases. Eur J Cardiothorac Surg. 1998;14(2):127-33.

4. Stern R, Berger S, Casaulta C, Raio L, Abderhalden S, Zachariou Z. Bilateral intralobar pulmonary sequestration in a newborn, case report and review of the literature on bilateral pulmonary sequestrations. J Pediatric Surg. 2007;42(4): E19-23.

5. Bratu I, Flageole H, Chen MF, Di Lorenzo M, Yazbeck S, Laberge JM. The multiple facets of pulmonary sequestration. J Pediatr Surg. 2001;36(5):784-90.
6. O'Mara CS, Baker RR, Jeyasingham K. Pulmonary sequestration. Surg Gynecol Obstet. 1978;147(4):609-16.

7. Corbett HJ, Humphrey GM. Pulmonary sequestration. Paediatr Respir Rev. 2004;5(1):59-68.

8. Mooney DP, Sargent SK, Pluta D, Mazurek P. Spiral CT: use in the evaluation of chest masses in the critically ill neonate. Pediatr Radiol. 1996;26(1):15-8.

9. Adzick NS, Harrison MR, Crombleholme TM, Flake AW, Howell LJ. Fetal lung lesions: management and outcome. Am J Obstet Gynecol. 1998;179(4):884-9.

10. Carpentieri DF, Guttenberg M, Quinn TM, Adzick NS. Subdiaphragmatic pulmonary sequestration: a case report with review of the literature. J Perinatol. 2000;20(1):60-2

11. Coulier B, Mailleux P, Van Cutsem O, Bachez P, Mairesse M Ledent C. Diagnosis of intralobar pulmonary sequestration using helical computed tomography angiography: apropos of 3 patients. JBR-BTR. 1999;82(1):6-10.

12. Grigoryants $V$, Sargent SK, Shorter NA. Extralobar pulmonary sequestration receiving its arterial supply from the innominate artery. Pediatr Radiol. 2000;30(10):696-8.

13. Pego-Fernandes PM, Freire $\mathrm{CH}$, Jatene FB, Beyruti $\mathrm{R}$, Suso FV, Oliveira AS. Seqüestro pulmonar: uma série de nove casos operados. J Pneumologia. 2002;28(4):175-9. 